\title{
Antibacterial and Anticoagulant Activities of Coumarins Isolated from the Flowers of Magydaris tomentosa
}

Sergio Rosselli ${ }^{1}$

Antonella Maggio ${ }^{1}$

Gabriella Bellone ${ }^{1}$

Carmen Formisano ${ }^{2}$

Adriana Basile ${ }^{3}$

Carla Cicala ${ }^{4}$

Alessio Alfieri $^{4}$

Nicola Mascolo 4

Maurizio Bruno ${ }^{1}$

\section{Abstract}

The phytochemical investigation of the acetone and methanol extracts of the flowers of Magydaris tomentosa (Desf.) DC afforded six known coumarins as well as (+)-meranzin hydrate (7), not previously reported as a natural product. The antibacterial activity of umbelliprenin (1), osthol (2), imperatorin (3), citropten (4) and (+)-meranzin hydrate (7) was tested against Gram-positive and Gram-negative bacteria. All coumarins (1-7) isolated in this study inhibited growth of all bacterial strains tested (MIC between 16 and $256 \mu \mathrm{g} / \mathrm{mL}$ ), the most active being imperatorin (3) (MICs between 32 and $128 \mu \mathrm{g} / \mathrm{mL}$ ) and citropten (4) (MICs between 16 and $256 \mu \mathrm{g} / \mathrm{mL})$. The anticoagulant activity of compounds 1-4 and 7 was also evaluated.

\section{Key words}

Magydaris tomentosa $\cdot$ Apiaceae $\cdot$ coumarins $\cdot(+)$-meranzin hydrate $\cdot$ antibacterial activity $\cdot$ anticoagulant activity

\section{Introduction}

Magydaris tomentosa (Desf.) DC. [syn.: M. pastinacea (Lam.) Paol.] belongs to the Apiaceae family and is a plant growing in Sicily and Sardinia [1]. The plant, 1 to $2 \mathrm{~m}$ in height, is characterized by a striated, sulcate, thick stalk with very large leaves and umbels with 40-50 pedicels with white flowers. The studies on M. pastinacea (Lam.) Paol. allowed the isolation of several glucosides from the fresh rhizomes [2], [3] and some known coumarins from the fruits [4]. Phytochemical studies on Magydarids panacifolia [5], the only other species of this genus investigated so far, allowed the isolation of magydardienol, a new irregular monocyclic diterpene, whose structure was corrected later [6] and shown to be identical to bonandiol, isolated from Bonannia graeca (L.) Halácsy (Apiaceae) [7], and of several coumarins [8].
$M$. tomentosa is a rare species which grows in the mountains of Sicily and causes skin irritations, as we could confirm after collecting the plant material. Here we report the results of studies on the antibacterial and anticoagulant activities of coumarins (1-4 and 7; Fig. 1) isolated from the acetone and methanol extracts of the flowers of $M$. tomentosa.

\section{Material and Methods}

\section{General}

Optical rotations were determined on a JASCO P-1010 digital polarimeter. ${ }^{1} \mathrm{H}$ - and ${ }^{13} \mathrm{C}-\mathrm{NMR}$, spectra were recorded in $\mathrm{CDCl}_{3}$ on a Bruker AC 250 E NMR spectrometer (Bruker; Rheinstetten, Germany), using the residual solvent signal ( $\delta=7.27$ in ${ }^{1} \mathrm{H}$ and $\delta=77.00$ in ${ }^{13} \mathrm{C}$ ) as reference. ${ }^{13} \mathrm{C}$-NMR assignments were determined by DEPT spectra. ESI-MS was obtained with an Applied

Affiliation

${ }^{1}$ Dipartimento di Chimica Organica, Università degli Studi di Palermo, Palermo, Italy

2 Dipartimento di Chimica delle Sostanze Naturali, Università degli Studi di Napoli “Federico II", Napoli, Italy

${ }^{3}$ Dipartimento di Biologia Vegetale, Università degli Studi di Napoli “Federico II", Napoli, Italy

${ }^{4}$ Dipartimento di Farmacologia Sperimentale, Università degli Studi di Napoli “Federico II”, Napoli, Italy

Correspondence

Prof. Dr. Maurizio Bruno $\cdot$ Dipartimento di Chimica Organica $\cdot$ Università degli Studi di Palermo .

Viale delle Scienze $\cdot$ Parco d'Orleans II $\cdot 90128$ Palermo $\cdot$ Italy $\cdot$ Phone/Fax: +39-091-596-905 .

E-mail: bruno@dicpm.unipa.it

Received July 27, 2006 • Accepted October 30, 2006

Bibliography

Planta Med 2006; 72: 116-120 @ Georg Thieme Verlag KG Stuttgart · New York

DOI 10.1055/s-2006-951772 · Published online November 24, 2006

ISSN 0032-0943 
<smiles>CC(C)=CCC/C(C)=C/CC/C(C)=C/COc1ccc2ccc(=O)oc2c1</smiles><smiles>COc1ccc2ccc(=O)oc2c1CC=C(C)C</smiles><smiles>CC(C)=CCOc1c2occc2cc2ccc(=O)oc12</smiles><smiles>COc1cc(OC)c2ccc(=O)oc2c1</smiles>

4<smiles>Cc1cc2ccc(=O)oc2c(OC[C@@H]2OC2(C)C)c1O</smiles>

5<smiles>CC(C)(O)[C@@H](O)COc1c2occc2cc2ccc(=O)oc12</smiles>

Biosystem API-2000 mass spectrometer (Applied Biosystems; Concord, Canada).

\section{Plant material}

The flowers of Magydaris tomentosa (Desf.) DC were collected in June 2005 near Godrano (Palermo) in Sicily, Italy and voucher specimens (PAL 05-608) were deposited in the Herbarium of the Botanical Garden of Palermo, Italy.

\section{Extraction and isolation}

Dried and powdered flowers (250 g) of $M$. tomentosa were extracted with $\mathrm{Me}_{2} \mathrm{CO}(5 \mathrm{~L})$ at room temperature for a week. After filtration, the solvent was evaporated to give a gum ( $21 \mathrm{~g})$ which was chromatographed on a silica gel (Merck No. 7734, deactivated with $15 \% \mathrm{H}_{2} \mathrm{O}, 400$ g; Merck; Darmstadt, Germany) column eluted with petroleum ether, petroleum ether-EtOAc mixtures and EtOAc. $500 \mathrm{~mL}$ fractions were collected as follows: $1-4$, petroleum ether; $5-8$, petroleum ether-EtOAc (3:2); 9-12, EtOAc. Fractions 3 and 4 were re-chromatographed on a silica gel column. Elution with $n$-hexane-EtOAc (9:1) gave umbelliprenin (1). Fractions 5-8 were re-chromatographed on a silica gel column. Elution with $n$-hexane-EtOAc (7:3) gave osthol (2), imperatorin (3), citropten (4) and (+)-heraclenin (5).

The plant material was further extracted with $\mathrm{MeOH}(5 \mathrm{~L})$ for a week at room temperature. After filtration and evaporation of the solvent, a gum $(8 \mathrm{~g})$ was obtained, which was chromatographed on a silica gel (Merck No. 7734, deactivated with 15\% $\mathrm{H}_{2} \mathrm{O}, 200 \mathrm{~g}$ ) column and eluted with petroleum ether-EtOAc $3: 7$ (2 L) and $\mathrm{CHCl}_{3}-\mathrm{MeOH}$ 4:1 (2 L). The fractions (250 $\mathrm{mL}$ each) eluted with $\mathrm{CHCl}_{3}-\mathrm{MeOH}$ were re-chromatographed on a silica gel column and then by preparative TLC (Merck, $2 \mathrm{~mm}$, EtOAc) to give heraclenol (6) and (+)-meranzin hydrate (7). The spectro- scopic data of these substance were in complete agreement with those reported in the literature.

Umbelliprenin (1): $50 \mathrm{mg}$; m.p. $63-64{ }^{\circ} \mathrm{C}$ (petroleum etherEtOAc); ${ }^{1} \mathrm{H}-\mathrm{NMR}$ and ${ }^{13} \mathrm{C}-\mathrm{NMR}$ : see Table $\mathbf{1}$.

Osthol (2): $500 \mathrm{mg}$; m.p. $83-84^{\circ} \mathrm{C}$ (petroleum ether-EtOAc).

Imperatorin (3): $1.55 \mathrm{~g}$; m.p. $102{ }^{\circ} \mathrm{C}$ (needles from petroleum ether- $\mathrm{Me}_{2} \mathrm{CO}$ ).

Citropten (4): $1.8 \mathrm{~g}$; m.p. $146^{\circ} \mathrm{C}$ (petroleum ether-Me $\mathrm{M}_{2} \mathrm{CO}$ ).

(+)-Heraclenin (5): 5 mg; m.p. $108-109^{\circ} \mathrm{C}(\mathrm{MeOH}) ;[\alpha]_{\mathrm{D}}^{22}:+21.1^{\circ}$ (c 0.10 , pyridine).

Heraclenol (6): $5 \mathrm{mg}$; m.p. $110-113^{\circ} \mathrm{C}(\mathrm{MeOH}) ;[\alpha]_{\mathrm{D}}^{22}:+11.1^{\circ}(\mathrm{c}$ 0.10 , pyridine).

(+)-Meranzin hydrate (7): $40 \mathrm{mg}$; m.p. $124-125^{\circ} \mathrm{C}$ (n-hexaneEtOAc); $[\alpha]_{\mathrm{D}}^{22}:+40.9^{\circ}$ (c $\left.0.34, \mathrm{CHCl}_{3}\right) ;{ }^{1} \mathrm{H}-\mathrm{NMR}\left(\mathrm{CDCl}_{3}, 250\right.$ $\mathrm{MHz}): \delta=7.62(1 \mathrm{H}, \mathrm{d}, J=9.5 \mathrm{~Hz}, \mathrm{H}-4), 7.35(1 \mathrm{H}, \mathrm{d}, J=8.7 \mathrm{~Hz}$, $\mathrm{H}-5), 6.88(1 \mathrm{H}, \mathrm{d}, J=8.7 \mathrm{~Hz}, \mathrm{H}-6), 6.55(1 \mathrm{H}, \mathrm{d}, J=9.5 \mathrm{~Hz}, \mathrm{H}-3)$, $3.94\left(3 \mathrm{H}, \mathrm{s}, \mathrm{OCH}_{3}\right), 3.64\left(1 \mathrm{H}\right.$, br dd, $\left.J=10.5,2.4 \mathrm{~Hz}, \mathrm{H}-2^{\prime}\right), 3.10$ $\left(1 \mathrm{H}, \mathrm{dd}, J=13.8,2.4 \mathrm{~Hz}, \mathrm{H}_{\mathrm{a}}-1^{\prime}\right), 3.00(1 \mathrm{H}, \mathrm{dd}, J=13.8,10.5 \mathrm{~Hz}$, $\left.\mathrm{H}_{\mathrm{b}}-1^{\prime}\right)$, 1. $34\left(6 \mathrm{H}, \mathrm{s}, \mathrm{CH}_{3}-4^{\prime}, \mathrm{CH}_{3}-5^{\prime}\right) ;{ }^{13} \mathrm{C} \mathrm{NMR}\left(\mathrm{CDCl}_{3}, 62.7\right.$ $\mathrm{MHz}): \delta=163.8$ (C, C-2), 160.5 (C, C-7), 153.3 (C, C-9), 143.9 (CH, C-4), 126.8 (CH, C-5), 115.8 (C, C-8), 113.0 (C, C-10), 112.7 (CH, C-3), 107.4 (CH, C-6), $78.0\left(\mathrm{CH}, \mathrm{C}-2^{\prime}\right), 72.8$ (C, C-3'), 56.1 $\left(\mathrm{CH}_{3}, \mathrm{OCH}_{3}\right), 25.9\left(\mathrm{CH}_{2}, \mathrm{C}-1^{\prime}\right), 25.4\left(\mathrm{CH}_{3}, \mathrm{CH}_{3}-4^{\prime}\right), 24.0\left(\mathrm{CH}_{3}\right.$, $\left.\mathrm{CH}_{3}-5^{\prime}\right)$. 
Table 1 Spectroscopic data of umbelliprenin (1) in $\mathrm{CDCl}_{3}$

\begin{tabular}{llrl}
\hline & H (J Hz) & \multicolumn{1}{l}{ C } & HMBC \\
\hline 2 & & 161.30 & H-4, H-3 \\
\hline 3 & $6.26 \mathrm{~d}(9.6)$ & 112.94 & \\
\hline 4 & $7.63 \mathrm{~d}(9.6)$ & 143.43 & $\mathrm{H}-5$ \\
\hline 5 & $7.37 \mathrm{~d}(8.1)$ & 128.66 & $\mathrm{H}-4$ \\
\hline 6 & $6.85 \mathrm{dd}(8.1,2.4)$ & 113.21 & \\
\hline 7 & & 162.15 & $\mathrm{H}-5, \mathrm{H}-8, \mathrm{H}-6, \mathrm{H}-1^{\prime}$ \\
\hline 8 & $6.82 \mathrm{~d}(2.4)$ & 101.57 & $\mathrm{H}-6$ \\
\hline 9 & & 155.86 & $\mathrm{H}-4, \mathrm{H}-5, \mathrm{H}-8$ \\
\hline 10 & & 112.41 & $\mathrm{H}-4, \mathrm{H}-6, \mathrm{H}-8, \mathrm{H}-3$ \\
\hline $1^{\prime}$ & $4.61 \mathrm{~d}(6.6)$ & 65.47 & \\
\hline $2^{\prime}$ & $5.48 \mathrm{brt}(6.6)$ & 118.41 & $\mathrm{H}-1^{\prime}, \mathrm{H}-4^{\prime}, \mathrm{Me}-12^{\prime}$ \\
\hline $3^{\prime}$ & & 142.39 & $\mathrm{H}-1^{\prime}, \mathrm{H}-5^{\prime}, \mathrm{Me}-12^{\prime}$ \\
\hline $4^{\prime}$ & $2.13 \mathrm{~m}$ & 39.51 & $\mathrm{H}-2^{\prime}, \mathrm{H}-10^{\prime}, \mathrm{H}-5^{\prime}, \mathrm{Me}-12^{\prime}$ \\
\hline $5^{\prime}$ & $2.15 \mathrm{~m}$ & 26.12 & $\mathrm{H}-4^{\prime}$ \\
\hline $6^{\prime}$ & $5.08 \mathrm{t}(6.6)$ & 123.47 & $\mathrm{H}-5, \mathrm{H}-8^{\prime}, \mathrm{Me}-13^{\prime}$ \\
\hline $7^{\prime}$ & & 135.58 & $\mathrm{H}-8^{\prime}, \mathrm{Me}-12^{\prime}$ \\
\hline $8^{\prime}$ & $1.97 \mathrm{~m}$ & 39.65 & $\mathrm{H}-10^{\prime}, \mathrm{H}-9^{\prime}, \mathrm{Me}-13^{\prime}$ \\
\hline $9^{\prime}$ & $2.05 \mathrm{~m}$ & 26.63 & $\mathrm{H}-8^{\prime}$ \\
\hline $10^{\prime}$ & $5.10 \mathrm{t}(6.6)$ & 124.28 & $\mathrm{Me}-14^{\prime}, \mathrm{Me}-15^{\prime}$ \\
\hline $11^{\prime}$ & & 131.43 & $\mathrm{H}-9^{\prime}, \mathrm{Me}-14^{\prime}, \mathrm{Me}-15^{\prime}$ \\
\hline $12^{\prime}$ & $1.78 \mathrm{~s}$ & 16.77 & $\mathrm{H}-2^{\prime}, \mathrm{H}-4^{\prime}$ \\
\hline $13^{\prime}$ & $1.60 \mathrm{~s}$ & 16.03 & $\mathrm{H}-6^{\prime}, \mathrm{H}-8^{\prime}$ \\
\hline $14^{\prime}$ & $1.69 \mathrm{~s}$ & 25.69 & $\mathrm{Me}-15^{\prime}$ \\
\hline $15^{\prime}$ & $1.59 \mathrm{~s}$ & 17.68 & $\mathrm{Me}-14^{\prime}$ \\
\hline & & & \\
\hline & & & \\
\hline
\end{tabular}

\section{Antimicrobial activity}

The antibacterial activity was evaluated by determining the minimum inhibitory concentration (MIC) using the broth dilution method [9]. The following twelve bacterial strains, selected as representative of the classes of Gram-positive and Gram-negative, were obtained from the American Type Culture Collection (ATCC; Rockville, MD, USA): Bacillus subtilis (ATCC 10774), Enterobacter aerogens (ATCC 13 048), Enterobacter cloacae (ATCC 10699), Enterococcus faecalis (ATCC 14428), Escherichia coli (ATCC 11229), Klebsiella pneumoniae (ATCC 10031), Proteus mirabilis (ATCC 7002), Proteus vulgaris (ATCC 12454), Pseudomonas aeruginosa (ATCC 27853), Salmonella typhi (ATCC 10699), Staphylococcus aureus (ATCC 13709) and Staphylococcus epidermidis (ATCC10875).

\section{Preparation of the compounds}

The samples were prepared by dissolving $10 \mathrm{mg}$ of the dry residue in $10 \mathrm{~mL}$ of sterile physiological Tris buffer, pH 7.4, $0.05 \mathrm{M}$ [10].

\section{Antimicrobial assay}

Bacterial strains were grown on MH agar plates (DIFCO; Detroit, MI, USA) and suspended in MH broth (DIFCO). The MIC values against bacterial strains were measured using the $\mathrm{MH}$ broth-dilution method [9]. The inoculum suspensions were prepared from $6 \mathrm{~h}$ broth cultures and adjusted to a $0.5 \mathrm{McF}$ arland standard turbidity. The compounds, sterilized by $0.45 \mathrm{~m}$ Millipore filters, were added to MH broth medium. Serial 10 -fold dilutions were made that furnished a concentration range from 1000 to $0.01 \mu \mathrm{g} / \mathrm{mL}$ for the compounds. The lowest concentrations of the solutions with activity underwent 2 -fold dilutions for a more ac- curate measurement of the MIC [11]. The bacterial suspensions were aerobically incubated for $24 \mathrm{~h}$ at $37^{\circ} \mathrm{C}$. The MIC was defined as the lowest concentration able to inhibit any visible bacterial growth. Control cultures, containing only sterile physiological Tris buffer were also prepared. In addition, MIC values for tetracycline hydrochloride (Pharmacia; Milano, Italy), benzylpenicillin sodium (Cynamid; Catania, Italy) and cefotaxime sodium (Roussel Pharmacia; Milano, Italy) were also determined in $\mathrm{MH}$ broth, using the standard method.

\section{Anticoagulant activity}

Ex vivo studies: All animal experiments complied with the Italian D.L. $\mathrm{n}^{\circ} 116$ of January 27, 1992 and associated guidelines in the European Communities Council Directive of November 24, 1986 (86/609/ECC). Compounds 1-4 and $\mathbf{7}$ were dissolved in ethanol and $\mathrm{H}_{2} \mathrm{O}$ (ratio $1: 1$ ) and both compounds and the vehicle control were intraperitoneally administered to male Wistar rats (200230 g; Harlan Nossan; San Pietro al Natisone, Italy), at the doses of 1,3 and $10 \mathrm{mg} / \mathrm{kg}$ once a day for 2 consecutive days. 20 hours following the second administration, rats were anesthetized with enflurane and blood was collected by cardiac puncture and anticoagulated with trisodium citrate $(3.8 \% \mathrm{w} / \mathrm{v} ; 1: 10)$. Plateletpoor plasma (PPP) was immediately prepared by centrifugation at $2500 \mathrm{rpm}$ for 15 minutes at $4{ }^{\circ} \mathrm{C}$. Anticoagulant activity was measured by a coagulameter (KoaguLab MJ Ortho Diagnostic Systems; Raritan, NJ, USA). To measure prothrombin time (PT), samples of $100 \mu \mathrm{L}$ of PPP were incubated at $37^{\circ} \mathrm{C}$ for $3 \mathrm{~min}$; coagulation was then induced by adding $200 \mu \mathrm{L}$ of prothrombin reagent (Ortho Diagnostic Systems).

\section{Results}

Examination of the acetone and methanol extracts of the flowers of Magydaris tomentosa yielded six known coumarins: umbelliprenin (1) [12], [13], osthol (2) [14], imperatorin (3) [15], citropten (4) [15], (+)-heraclenin (5) [16] and (-)-heraclenol (6) [4]. Another coumarin, (+)-meranzin hydrate (7), was also found, which has never previously been isolated, only the enantiomer being known as natural product [17]. The (+)-meranzin hydrate (7) has been synthesized starting from the coumarin turtuoside [18]. Herein, we present the results of an extensive 2D spectroscopic study (HSQC, HMBC, COSY) on umbelliprenin (1) that allowed us to give full ${ }^{1} \mathrm{H}$ - and ${ }^{13} \mathrm{C}$-NMR assignments (Table $\mathbf{1}$ ) not previously reported; therefore the published data [13] are amended. Coumarins isolated in this study inhibited all bacterial strains (MIC between 16 and $256 \mu \mathrm{g} / \mathrm{mL}$ ). In the antibacterial test, the most active were imperatorin (3) (MICs between 32 and $128 \mu \mathrm{g} / \mathrm{mL}$ ) and citropten (4) (MICs between 16 and $256 \mu \mathrm{g} /$ $\mathrm{mL}$ ). Except for Bacillus subtilis, both Gram-positive and Gramnegative bacteria displayed the same sensitivity to tested coumarins, with MICs between 32 and $64 \mu \mathrm{g} / \mathrm{mL}$. Bacillus subtilis was the least sensitive strain (MIC between 128 and $256 \mu \mathrm{g} / \mathrm{mL}$ ) (Table 2).

Compounds 1-4 at the dose of 3 and $10 \mathrm{mg} / \mathrm{kg}$ i.p. significantly $(\mathrm{P}<0.01)$ prolonged the PT compared to control samples. Conversely, compound 7 , at the same doses, significantly $(\mathrm{P}<0.01)$ reduced the PT value (Fig. 2). Therefore, none of the compounds tested showed anticoagulant activity at the doses of $1 \mathrm{mg} / \mathrm{kg}$ i.p. 
Table 2 Antibacterial activity of compounds $\mathbf{1 - 4}$ and $\mathbf{7}$

\begin{tabular}{|c|c|c|c|c|c|c|c|c|}
\hline Bacteria & 1 & 2 & 3 & 4 & 7 & Cefotax. & Penicil. & Tetrac. \\
\hline Enterococcus faecalis (ATCC 14428) & 64 & 64 & 32 & 32 & 64 & $\mathrm{R}$ & 2 & 2 \\
\hline Staphylococcus epidermidis (ATCC10875) & 64 & 32 & 32 & 32 & 64 & 0.1 & 0.03 & 0.1 \\
\hline Staphylococcus aureus (ATCC 13709) & 128 & 64 & 32 & 16 & 128 & 2 & 0.03 & 2 \\
\hline Bacillus subtilis (ATCC 10774) & 256 & 256 & 128 & 256 & 256 & 32 & 32 & 2 \\
\hline Enterobacter aerogenes (ATCC13048) & 128 & 128 & 32 & 32 & 128 & $\mathrm{R}$ & R & 4 \\
\hline Klebsiella pneumoniae (ATCC277736) & 128 & 64 & 32 & 64 & 128 & 0.1 & R & 16 \\
\hline Proteus mirabilis (ATCC 7 002) & 128 & 32 & 32 & 32 & 256 & 0.03 & 4 & 32 \\
\hline Proteus vulgaris (ATCC12454) & 64 & 64 & 64 & 64 & 128 & 0.03 & R & 4 \\
\hline Pseudomonas aeruginosa (ATCC 27853 ) & 128 & 128 & 64 & 64 & 256 & 1.6 & $\mathrm{R}$ & 32 \\
\hline Salmonella typhi (ATCC 19430) & 64 & 128 & 64 & 64 & 128 & 0.5 & 4 & 1 \\
\hline
\end{tabular}

a Values represent MIC values expressed in $\mu \mathrm{g} / \mathrm{mL}$. A comparison is shown between the antibiotic activity of the compounds with reference antibiotics: (cefotax.) Na cefotaxime, (penicil.) benzylpenicillin sodium, (tetrac.) tetracycline.

$\mathrm{R}=$ absence of inhibition even at the highest concentration used $(1000 \mu \mathrm{g} / \mathrm{mL})$.

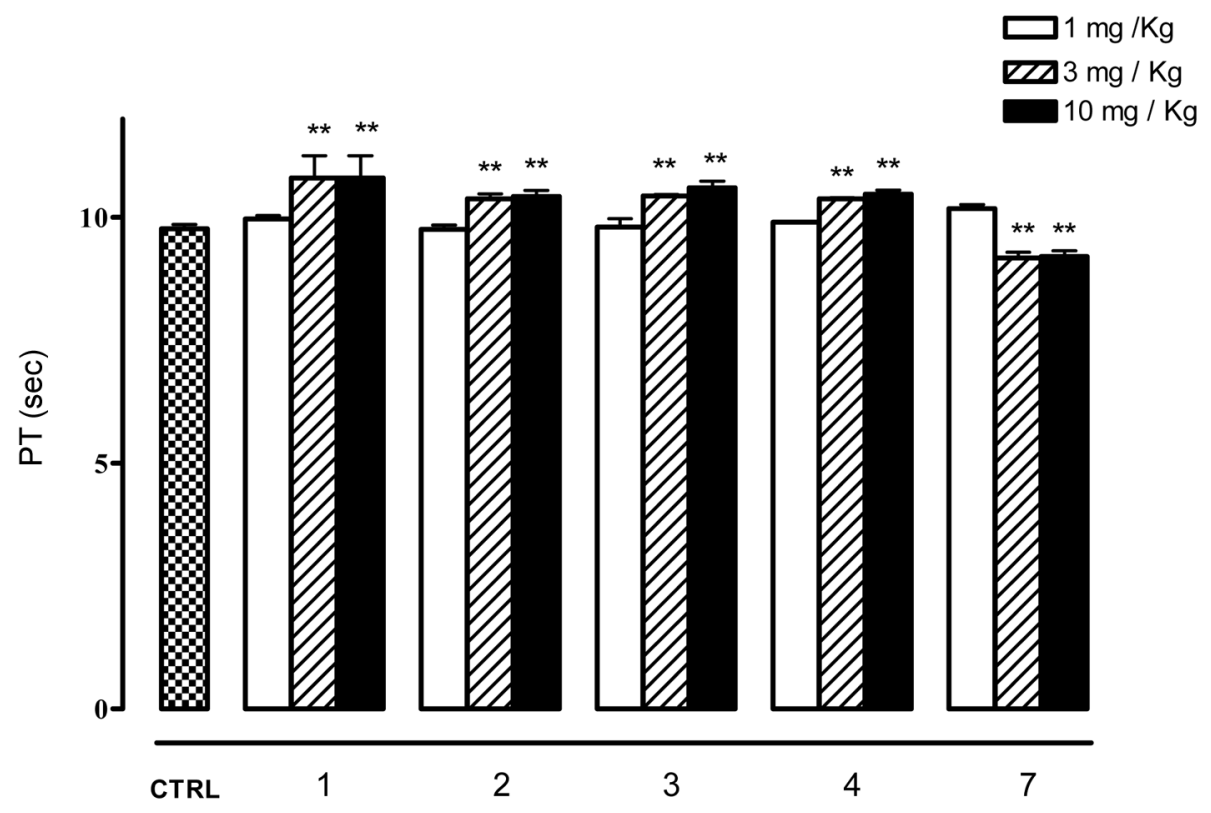

Fig. 2 Anticoagulant activity of compounds 1-4 and 7. PT value measured on rat plasma following 2 days treatment with compounds $\mathbf{1 - 4}$ and 7 (1-10 $\mathrm{mg} / \mathrm{kg}$ i.p.). ${ }^{* *} \mathrm{p}<0.01$ vs. control (CTRL; Dunnett's test).

\section{Discussion}

As for antibacterial activity, the tested coumarins were active both against Gram-negative and Gram-positive bacteria. This finding is interesting because conventional antibiotics are often more active against Gram-positive than Gram-negative bacteria. Even the particularly resistant Pseudomonas aeruginosa is inhibited by the substances. The pattern of chemical selectivity towards Gram-positive bacteria is not restricted to compounds from plants, but is a general phenomenon observed among most antibiotics. The antibacterial activity of plant extracts against Gram-negative bacteria has been shown in others studies. The extracts from some bryophytes, pteridophytes and edible fruits are active mainly against Gram-negative bacteria that are antibiotic-resistant such as Pseudomonas aeruginosa [19], [20], [21], [22]. Contrary to the literature, the antibacterial activity of the tested coumarins is directed both against Gram-positive and Gram-negative bacteria. Among the tested coumarins, impera- torin (3) and citropten (4) are the most active. The substances' activities show that the antibacterial activity is mainly due to the coumarin ring and that substituents can modulate the potency.

Ex vivo studies show that compounds 1-4 exert anticoagulant activity in a test generally and widely used to estimate anticoagulant agents [23]. It is worth noting that compound 7, carrying two hydroxy groups on the side chain, exhibits a pro-coagulant activity as demonstrated by the shortening of the PT value.

\section{Acknowledgements}

The mass spectra were recorded at the "C.S.I.A.S." of the University "Federico II", Napoli. The assistance of the staff is gratefully appreciated. 


\section{References}

${ }^{1}$ Pignatti S. Flora d'Italia, Vol. 2. Bologna: Ed Agricole; 1982: 211

${ }^{2}$ Cerri R, Pintore G, Dessi G, Asproni B, Piseddu G, Sini S. Isolation, characterization and pharmacological activity of Magydaris pastinacea glucosides. Farmaco 1995; 50: $841-8$

${ }^{3}$ Cerri R, Dessi G, Manconi PM, Serra D, Pau A. Glycosides of the Magydaris pastinacea L. Pharmacol Res Commun 1988; 20: 109-12

${ }^{4}$ Camarda L, Di Stefano V, Lentini F, Mazzola P. Coumarins from the fruits of Magydaris pastinacea. Fitoterapia 1996; 67: 282

${ }^{5}$ De Pascual Teresa J, Grande C, Grande M. Chemical components of Umbelliferae. Magydardiendiol, diterpenoid with a new skeleton from Magydaris panacifolia (Umbelliferae). Tetrahedron Lett 1978; 19: $4563-6$

${ }^{6}$ Nagano H, Masunaga Y, Matsuo Y, Shiota M. Synthesis of 2,6-dimethyl-6-(8-methyl-4-methylene-7-nonenyl)-2-cyclohexene-1-methanols from $\alpha$-santonin. Bull Chem Soc Jpn 1987; 60: 707 - 11

${ }^{7}$ Bruno M, Lamartina L, Lentini F, Pascual C, Savona G. Bonandiol: a new irregular, monocyclic diterpene from Bonannia greca (L.) Halacsy (Umbelliferae). Tetrahedron Lett 1984; 25: 4287-90

${ }^{8}$ Pinar M. Coumarins of Magydaris panacifolia, Cachrys sicula, Cachrys libanotis and Lafuentea rotundifolia. Anal Quim 1977; 73: 599-600

${ }^{9}$ Erricson HM, Sherris JC. Antibiotic sensitivity testing: report of an international collaborative study. Acta Pathol Microbiol Scand [B] Microbiol Immunol 1971; 217: 1 -90

${ }^{10}$ Ieven M, Dirk A, Vanden Berghe V, Francis M, Vlietinck A, Lammens E. Screening of higher plants for biological activities I. Antimicrobial activity. Planta Med 1979; 36: $311-21$

${ }^{11}$ Basile A, Spagnuolo V, Giordano S, Sorrentino C, Castaldo Cobianchi R. Effect of $\alpha$-D-galacturonides in Nephrolepis sp. Int J Antimicrob Agents 1997; 8: $131-4$
${ }^{12}$ Kir'yalov NP. The structure of cocanikine and umbelliprenin, components of the neutral part of oil from Ferula cocanica. Tr Akad Nauk SSSR Inst Botan 5; 1961: 7-14

${ }^{13}$ Iranshahi M, Amin G-R, Jalalizadeb H, Shafiee A. New germacrane derivative from Ferula persica. Pharm Biol 2003; 41: 431 -3

${ }^{14}$ Chatteryee A, Baneryi J, Basa SC. Loctonic constituents of Prangos pabularia Lindl. (Umbelliferae). Tetrahedron 1972; 28: 5175-82

${ }^{15}$ Steck W, Mazurek M. Identification of natural coumarins by NMR spectroscopy. Lloydia 1972; 35: 418-39

${ }^{16}$ Sharma YN, Zaman A, Kindwai AR. Chemical examination of Heracleum candicans. Isolation and stucture of a new furocoumarinheraclenin. Tetrahedron 1964; 20: 87-90

17 Kuznetsova GA, Abyshev AZ. Natural (-)-7-methoxy-8-( $\beta, \gamma$-dihydroxyisopentyl)coumarin. Khim Prirodn Soedin 1965; 1: 283-8

18 Ceccherelli P, Curini M, Marcotullio MC, Madruzzza G. Tortuoside, a new natural coumarin glucoside from Seseli tortuosum. J Nat Prod 1990; 53: $536-8$

${ }^{19}$ Basile A, Sorbo S, Giordano S, Lavitola A, Castaldo Cobianchi R. Antibacterial activity in Pleurochaete squarrosa extract (Bryophyta). Int J Antimicrob Agents 1998; 10: 169-72

${ }^{20}$ Basile A, Vuotto ML, Ielpo MTL, Moscatiello V, Ricciardi L, Giordano S et al. Antibacterial activity in Rhynchostegium riparioides (Hedw.) Card. Extract (Bryophyta). Phytoter Res 1998; 12: 146-8

${ }^{21}$ Basile A, Giordano S, López-Sáez JA, Castaldo Cobianchi R. Antibacterial activity of pure flavonoids isolated from mosses. Phytochemistry 1999; 52: 1479-82

22 Vuotto ML, Basile A, Moscatiello V, De Sole P, Castaldo Cobianchi R, Laghi E et al. Antimicrobial and antioxidant activities of Feijoa sellowiana fruit. Int J Antimicrob Agents 1999; 13: 97 - 201

${ }^{23}$ Kazuo S, Kaku S, Hirayama F, Koshio H, Matsumoto Y, Kawasaki T et al. Antithrombotic effect of YM-75466 is separated from its effect on bleeding time and coagulation time. Eur J Pharmacol 1998; 352: 59 63 